\title{
Free Primary Education: Quality And Teacher's Dilemma
}

\author{
Agnes W. Gathumbi, (Email: AgnesGath@africaonline.co.ke), Kenyatta University, Kenya
}

\begin{abstract}
The current government's overall goal within education remains to achieve Education for All (EFA) by 2015, with the top policy objectives being to ensure equitable access and improvement in quality and efficiency. In January 2003, the Kenya government made a significant step towards this vision by announcing Free Primary Education. While this was a laudable goal, it brought with it other problems. An additional 1.3 million children were enrolled in schools. The rapid increase in numbers has triggered widespread concern about the quality of education. This paper discusses the problems teachers have to grapple with, particularly in the absence of additional targeted resources to the education sector. The paper also makes recommendations.
\end{abstract}

\section{INTRODUCTION}

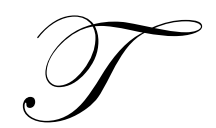

he need for governments to commit themselves to make universal education a reality were articulated during the meeting of ministers of education at Jomtien, Thailand in 1990. A decade later, six Education for All (EFA) goals of the Dakar Framework were set for 2015 with the aim of reducing illiteracy by $50 \%$. The main issue emerging from the six goals is the need for equitable access to literacy for all by 2015. The reason why UN was concerned with world literacy, was after the realization that in one-decade, the literacy rates had gone down from $24.7 \%$ in 1990 to $20.3 \%$ in 2000, (UNESCO, 2002). As a result, the United Nations Literacy Decade was proclaimed to be 2003 - 2012. An appeal was, therefore, sent to all governments to reinforce political will, mobilize adequate national resources and intensify their efforts and resources to ensure that by 2015 all children, particularly females, children in difficult circumstances, and those belonging to ethnic minorities, have access to complete, free and compulsory education of good quality. In 2000, world leaders met in New York and agreed to reduce global poverty by ensuring that every child was able to complete elementary school education by 2015.

In 2002, the world bank officially put a policy in place opposing charging of school fees and supporting free primary initiative. Most countries in Africa are under pressure to provide free primary education of good quality (New York Times.com, 2004).

The need to universalise access to quality education (QE) is a key element of policy considerations in Kenya. The concept of quality education is defined in part, in Article 1 in the World Declaration for EFA, adopted in 1990 that states:

All children have the human right to benefit from an education that will meet their basic learning needs in the best and fullest sense of the term, an education that includes learning to know, to do, to live together and to be. (WDEFA: 1990)

Quality education plays a major role in promoting economic growth, enhancing democracy and good governance. Education contributes to improving people's lives and reducing poverty in ways that help people become more productive and earn more (World bank: 1999). Making QE accessible to all children calls for re-examination of practices that exist within the policy context, national examinations conduct, teacher trainee recruitment and consequent training, curriculum development and implementation procedures, the teaching/ learning process as well as quality assurance. 
In an exploratory study conducted in 2000, key stakeholders in Kenya, Uganda and Zimbabwe (especially parents), when asked what quality education entailed, said that they wanted children to be able to progress through the education system, do well in examinations and leave with employable skills.

Stakeholders' views sought in a recent exploratory study done in 2000 on language policy and practices in primary schools, equated QE to being able to speak English fluently. They made it clear that at the end of primary school, learners should be able to communicate fluently and accurately in English whenever required to do so in their everyday activities. The same views were expressed in a recently concluded English Literacy Norms project (Muthwii, 2001, ELN, 2004). Lack of literacy skills among primary school leavers is of concern among stakeholders as such skills are required if learners want to pursue further education. Research has also shown that only 1 in every 3 pupils who start primary school leave literate. There is also the problem of retention as the dropout rate is high. For example, statistics from the government show that in 1987, out of 918,300 grade one cohort, only 408,300 (44\%) reached grade eight in 1994, which was the end of the primary school course. Out of the $44 \%$ who completed, only $140,980(28.5 \%)$ were literate in English, which is inter alia the language of instruction, examinations and textbooks.

In a National Conference on Education in Kenya held in November 2003, the issue of QE was raised. The general agreement was that the existing disparities in access to QE have the danger of creating a market place in knowledge that excludes certain groups of the population. Such a scenario allows a situation to persist where there are the "haves" and the "have-nots". Apart from the stakeholders in education, the media too has been commenting on lack of literacy competences among school leavers at all levels of education.

The current Kenya government's overall goal within education remains to achieve Education for All (EFA) by 2015 , with the top policy objectives being to ensure equitable access and improvement in quality and efficiency. In March 2003, the newly elected government of Kenya announced Free Primary Education (FPE) as a significant step towards this vision. Currently, 50\% of the country's Gross National Product (GNP) goes to education. Since the new government came to power, expenditure on education has increasing from 8 billion shilling in 2002-2003, to 10.5 billion in 2003-2004. Despite the government's concerted effort to provide education to all children, the issue of the type of education provided cannot be ignored. There are identified variables critical to provision of QE.

\section{ISSUES OF QUALITY EDUCATION}

From the research done and government policies, the issue of QE has been of concern to all. With the introduction of FPE in 2003, certain issues have emerged. There has been expansion in terms of enrolments without revitalization. Government declarations are made without putting in place facilities to accommodate the large numbers of new entrants. So far, 1.3 million pupils of varied ages (5-84 yrs.) have enrolled in school since the declaration of FPE and 1.5 million are yet to enrol. At the moment, the government seems to be more concerned with numbers than with the type of education being offered in schools.

Parents' aspirations have been to send their children to school with the expectation that they would come out literate with employable skills. However, their expectations have been dashed. After investing heavily in education, schools are churning out large numbers $(2 / 3)$ of either illiterate or semi-literate primary school leavers.

Implementation of education policies is another major variable in the provision of quality education. Lack of proper implementation of the policies has been found to play a negative role as ignorance or non-adherence to policy statements has acted as a hindrance to attainment of expected competences. For example, learners reach grade 4 when they are expected to learn in English as the Language of Instruction (LOI), having not attained the desirable competences that would enable them to cope with the challenges of learning in English. Other languages taught and used at grades $1-3$ namely, Kiswahili and mother tongue are also not well developed.

There has been promotion of female quantitative access where much emphasis has been put on enrolling more girls to school. The need to increase girls' enrolments has not taken into account their growing up needs in order to retain them in school. This has resulted in persistent drop out rates. The table below helps to explain this scenario 
by showing the enrolment rates vs. drop out rates in one rural district where performance in national examinations is usually poor.

\section{ENROLMENT RATES VS. DROP-OUT RATES}

\begin{tabular}{|l|c|c|c|c|c|c|c|c|c|}
\hline & \multicolumn{3}{|c|}{ Enrolment } & \multicolumn{3}{c|}{ Drop-Outs } & \multicolumn{3}{c|}{ Drop-Out Rates - \% } \\
\hline Class & Males & Females & Total & Males & Females & Total & Males & Females & Total \\
\hline Primary 1 & 6,809 & 6,684 & 13,493 & 427 & 414 & 841 & 6.3 & 6.2 & 6.2 \\
\hline Primary 2 & 6,251 & 6,050 & 12,301 & 412 & 371 & 783 & 6.6 & 6.1 & 6.4 \\
\hline Primary 3 & 5,715 & 5,657 & 11,372 & 525 & 503 & 1,028 & 9.2 & 8.9 & 9.0 \\
\hline Primary 4 & 5,155 & 5,283 & 10,438 & 584 & 491 & 1,075 & 11.3 & 9.3 & 10.3 \\
\hline Primary 5 & 4,303 & 4,786 & 9,089 & 519 & 442 & 961 & 12.1 & 9.2 & 10.6 \\
\hline Primary 6 & 3,947 & 4,517 & 8,464 & 523 & 534 & 1,057 & 13.3 & 11.8 & 12.5 \\
\hline Primary 7 & 3,617 & 4,529 & 8,146 & 511 & 685 & 1,196 & 14.1 & 15.1 & 14.7 \\
\hline Primary 8 & 2,264 & 2,822 & 5,086 & 65 & 120 & 185 & 2.9 & 4.3 & 3.6 \\
\hline Total & $\mathbf{3 8 , 0 6 1}$ & $\mathbf{4 0 , 3 2 8}$ & $\mathbf{7 8 , 3 8 9}$ & $\mathbf{3 , 5 6 6}$ & $\mathbf{3 , 5 6 0}$ & $\mathbf{7 , 1 2 6}$ & $\mathbf{9 . 4}$ & $\mathbf{8 . 8}$ & $\mathbf{9 . 1}$ \\
\hline
\end{tabular}

Data in the above table were collected in 1999. The statistics show a higher dropout rate is experienced between the $4^{\text {th }}$ and $7^{\text {th }}$ year of schooling. Many of the pupils reach puberty around this time and in some communities, the adolescents are regarded as grown ups, which does not help much in retaining them in school. In some communities, girls are forced into marriage around this time resulting in early marriages. Other causes of an increase in girls' drop out rate are teenage pregnancies and child labour. Overall, 9.1\% of the pupils dropped out before finishing the eight years of primary schooling. One unique finding from the above data is that more males drop out of school than female pupils. This finding was not anticipated, as it was the belief of many that more girls drop out of school than boys. This situation was prevalent probably because at this time (ages $10-14$ ), some boys from poor backgrounds go out to look for work to provide food and other basic necessities for their families. Provision of QE would ensure that those dropping out of school have the necessary academic and life skills to function as useful members of the society. It would also be easier for them to learn a trade or vocation, as they would be able to gather knowledge from printed sources.

\section{VARIABLES CRITICAL TO PROVISION OF EDUCATION}

One key variable that has been regularly identified as an important factor that impacts educational quality and relevance is the ability to read. It is predicated that in addition to being an important learning competence, reading is an essential tool in accessing content and skills in other school subjects. Recognition of the importance of reading mastery notwithstanding, there is evidence that the reality in the school system is far below the ideal. For instance, the results of a 1998 criterion-referenced reading test administered to a representative national sample, indicated that $77 \%$ of Kenyan grade 6 pupils had not attained the reading mastery level deemed desirable for successful learning in grade 7 (SAQMEC, 2000). Apart from the reading skill, there are other variables that are critical to the provision of QE.

The following diagram of eight variables that are critical in the provision of quality education have been inadequately addressed in the dispensation of education in Kenya. They have been found to be contributory in lowering the standards of education in Kenya. 


\section{VARIABLES CRITICAL TO QE}

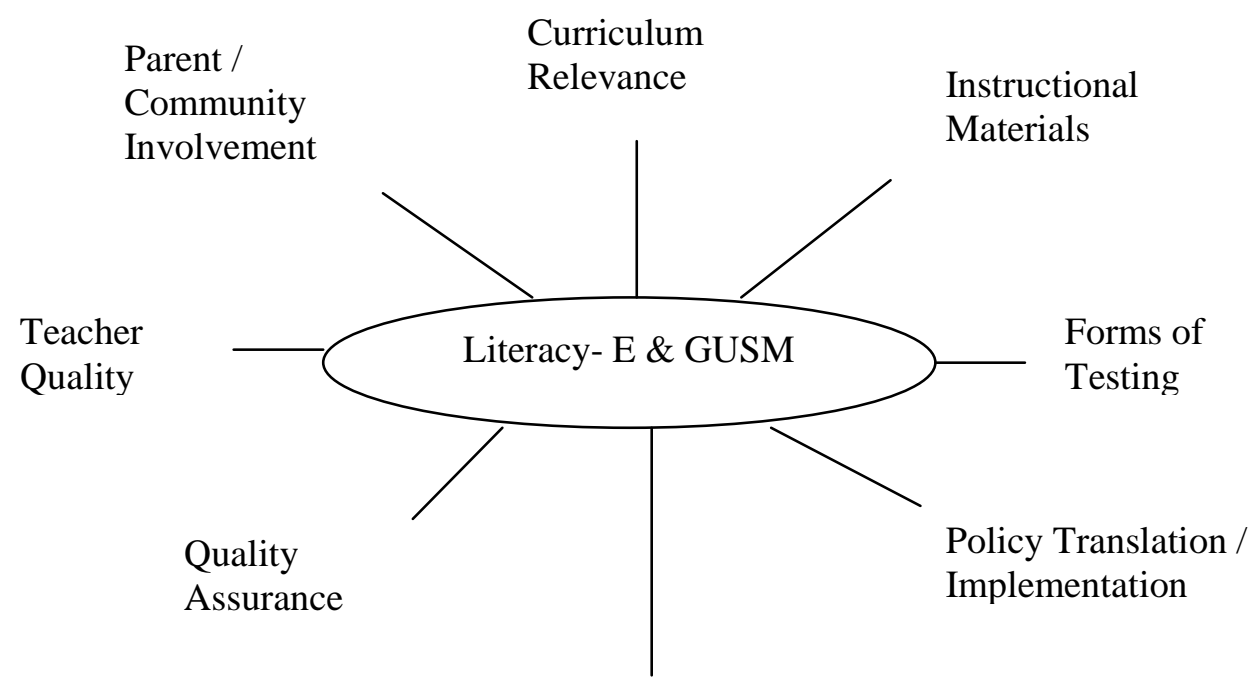

Learning Environments

\section{TEACHER QUALITY}

The academic qualifications of the teacher as well as professional training given have been found to be wanting. The teacher lacks the expected English language competences s/he is expected to use to teach other subjects. Many had the lowest aggregate grade of D+ at Kenya Certificate of Secondary Education (KCSE) and the majority had failed in English and Mathematics. Many had low entry grades to Primary Teacher Training Colleges (PTTCs). Without proper grounding in the proper teaching methods, teachers will continue to be ill equipped to handle the curricula. At school, there is no emphasis and support to teach literacy skills, especially in the basic years of schooling, thereby resulting to under-teaching at grades 1,2 and 3 . The quality of the teacher determines the quality of education (Lewin 1983).

Apart from the above personal shortcomings, primary school teachers in Kenya face specific challenges in trying to provide QE. For example, there are no clear set practical guidelines on how to interpret and teach the content in the syllabi, and consolidate and assess the mastery of knowledge and skills learnt at different grade levels. There is also negligible investment of time by most schools to teach literacy and resources to buy non-textbook materials. There are no mechanisms put in place to ensure access to, and use of the available resources by all pupils throughout the school cycle. Many teachers lack an understanding of the existing education policies and their implications in providing QE.

\section{CURRICULUM RELEVANCE}

The curriculum has been found lacking in some of the information needed for proper implementation. For example, the concept of mastery of literacy is not clearly articulated beyond the general and specific objectives of the syllabus. There is also an assumption by teachers that all children have gone through pre-school that is erroneous. Many learners, especially those in rural areas, do not attend pre-school before joining grade one. This assumption has created a misconception among teachers that children enter school having acquiring reading skills from pre-school. They, therefore, ignore starting with the basic reading skills like the phonics, which is disadvantageous to those who have not acquired such skills. Most syllabuses are also too opaque, bundled and expert-oriented. For example, the English language syllabus does not enable teachers to teach in a balanced manner various language skills. It also does not provide sufficient guidance on what specific competences pupils have to develop in each of the language skills 
and how a teacher can continuously assess pupils' acquisition and mastery of such competences. The curriculum does not give sufficient guidance on possible remedial work to be given to pupils who lack particular competences or ways of writing competence-based reading materials and tests.

On the issue of retaining girls to school, key information on puberty and its effects comes after adolescence and is not geared to helping learners manage the consequences of puberty. This vital information is scattered in various textbooks and yet teachers lack the ability to synthesize the information into a body of knowledge.

\section{INSTRUCTIONAL MATERIALS}

Provision/acquisition and utilization of instructional materials have greatly affected provision of QE. Until 2003, it was the responsibility of the parents to provide all the materials needed in school. Many parents could not afford to buy textbooks and non-textbook reading materials. In most rural schools, the ratio of sharing textbooks was 1:4. Consequently, many learners could not learn independently or even do home work from the textbooks. Writing materials were also difficult to obtain especially among the economically disadvantaged parents resulting in many pupils going to school without exercise books or pencils.

However, after the declaration of FPE in March 2003 by the new government, a program to provide primary school learners with free educational materials was started. The sharing of textbooks ratios is now 1:2 in grades $4-8$ and 1:3 in grades $1-3$. This welcome initiative has been negatively affected by government bureaucracy that has caused delays in sending money to schools to buy materials. Even though policy now includes provision of supplementary non-textbook materials, this is stifled by head-teachers' preference of textbooks. Teaching in Kenya, and indeed in other developing countries is greatly influenced by examinations that have caused negative backwash effects. What is not tested is not taught and therefore the aim is to cram content from textbooks, not to get life-long education. After all, ability to read fluently is not one of the skills examined in the public national examinations. There is also the problem of laxity by teachers as there is no optimal use of whatever materials are available in schools.

\section{FORMS OF TESTING}

National public examinations are set and conducted by the Kenya National Examinations Council (KNEC). Norm-referenced Testing (NRT) is used to conduct examinations which are done at the end of 8 years primary school and four years secondary school cycles, when learners are declared either successful or failures. No national examinations are given at various stages of the course to establish learners' weaknesses before the summative examinations. Preoccupation with NRT approach at the end of the school cycle restricts full use of the syllabus, both at school and at primary teacher education. As teaching and learning are examination-oriented, negative backwash effects have caused some skills in the syllabus to be ignored by teachers. For example, in English, listening and speaking skills are not examined by KNEC and consequently, teachers do not put much emphasis on them when teaching. This has resulted in producing learners who cannot communicate fluently in English.

\section{PARENT/COMMUNITY INVOLVEMENT}

Although parents have aspirations for their children, there is absence of meaningful parental follow-up of what goes on in school. There is inadequate community participation at the school level. Many are ignorant of their role in ensuring provision of quality education for their children. Over $60 \%$ are either illiterate or semi-literate which makes them feel inadequately prepared to involve themselves with school matters. Head teachers too do not encourage interaction, making school remain the domain of the head teacher and the teachers.

\section{POLICY INTERPRETATION AND IMPLEMENTATION}

A gap exists between the way education policies are stated and the way they are interpreted, which is contrary to the original policy statements. Teachers and other stakeholders in education are either unaware or ignorant of the policies and their implications. For example, heads of schools have ignored the policy on book ratios by not spending $30 \%$ of the allocated funds on buying non-textbook materials. Again, curriculum mandated library lessons 
are misused for other purposes. Reading, a skill used in a library lesson, is not considered a vital skill since it is not examined at the national level. The irony is that the reading skill is needed if one is to understand what the examination questions mean and the expected responses. On the side of sanitation, the outdated policy on school environmental sanitation that has only moved from requiring a generally clean to a congenial environment is still in existence. In some severe cases in rural schools, the ratio of toilet to pupils is 1:1000. This affects learning as not all pupils would be able to use the toilet within the given break time. Lastly, the policy on the provision of water and waste disposal facilities is ignored, especially in rural schools, yet the ministry of education is silent about it. The conclusion that can be drawn from this scenario is either that the policies are not well communicated to the users or their implications are not well understood.

\section{LEARNING ENVIRONMENT}

To provide QE, there has to be properly managed learning environment, combining all the human and material resources and paying attention to the physical, intellectual and emotional aspects of pupils and teachers. There is need to provide a congenial atmosphere that enhances quality learning and makes teaching and learning enjoyable. The reality is that the learning environment is not conducive to learning, especially in rural and urban slums' schools. There is lack of proper basic infrastructure, a situation that de-motivates both teachers and pupils. Head teachers' managerial skills are autocratic as they hardly consult before making decisions. This attitude might have contributed to the teachers' low morale. Poor management of human resources and other resources is evident in schools. For example, learners receive harsh punishments for petty offences, which keep some pupils out of school. In some schools, the heads are rude to parents making them feel unwelcome in school. In a few cases, male teachers become intimately involved with teenage girls resulting in teenage pregnancies. In other cases, the school head may be insensitive or indifferent to girls' growing up gender needs. Lack of proper knowledge on growing up and sexual maturation issues, as well as inadequate clean water and sanitation facilities cause girls to miss school at least three days each month. This acts as a hidden barrier to acquisition of $\mathrm{QE}$ as the knowledge that is missed during their absence is not repeated for them.

\section{QUALITY ASSURANCE}

Supervision of schools is hampered by lack of material support since in some cases, school inspectors fail to go to the field due to lack of transport. There is also the aloof attitude of the inspector that has created distrust in the teachers and school heads. Shortage of qualified manpower and resources has resulted in lack of enforcement of QE. This has also caused lack of follow up on inspection reports by school inspectors. At the same time, there is no systematic evaluation mechanism to specifically assess attainment of various competences. There is also lack of proper channelling of information from the Ministry of education to the intended recipients. For example, some circulars may not reach the schools and if they do, they arrive late thereby delaying the implementation of the policies. At the school level, there is lack of initiative as they wait to be directed physically for fear of making the wrong decisions. There is also the issue of corruption in some cases which compromises integrity on the part of those in responsible positions. In an effort to provide QE, the government in 2004 converted the former inspectorate department in the Ministry of education into a Quality Assurance department. Its mandate is to improve and maintain quality standards in education at all levels, except at the university.

\section{OTHER PERSISTENT CHALLENGES}

\section{The Impact of HIV/AIDS}

The HIV/Aids pandemic has impacted negatively on provision of QE. The country has lost qualified teachers, heads of schools and parents who leave school-going children orphaned. Many of the children end up dropping out of school. Poverty too is a major drawback as it is not possible to provide resources necessary in providing $\mathrm{QE}$. 


\section{Mobility and Brain Drain}

The country has been losing qualified manpower that migrates to other countries especially in the west, where pay and conditions of service are better. Some have been going to the South African countries where pay is better. In some cases, teachers are transferred arbitrarily before they have had a chance to settle down to proper teaching.

\section{Power of the Big Donors}

Major donors like the World Bank and IMF have had an influence on policies. Sometimes they push for policies that are not a priority for the particular country. This misdirects the much-needed funds.

\section{Bureaucratic Directives}

Bureaucracies like presidential directives have caused redirection of energies. For example, the Minister of education gives a directive today and after some months or even weeks, the president overturns it by giving a different directive with no explanation at all. This was quite common in the previous regime. Such declarations disorient the implementers.

\section{Sector-wide Approach}

Sector wide approach to policies and funding can cause delays and might stifle good education programs. This happens when the little resources available have to be divided between various government departments.

\section{WINDOWS OF OPPORTUNITY}

All is not lost as there are windows of opportunity that will help in the development of QE. To begin with, demand for quality education at grassroots level is increasing. Issues of $\mathrm{QE}$ are increasingly becoming central as evidenced in a recently conducted Joint Review Mission (JRM) involving the Ministry of Education and Donor agencies involved in provision of education. The main purposes of the JRM were to find out the conditions under which learning was taking place under the new FPE and how the provided learning materials were being utilized.

There is a new atmosphere and shift in attitude among policy makers in demanding and valuing quality research. The new government is encouraging universities to conduct research in partnership with government departments, to make it easy to institutionalize research findings. Through lobbying and expression of concern about the calibre of primary school teachers by researchers and other stakeholders, the government has raised the entry grade to Primary Teacher Training Colleges to ' $\mathrm{C}$ ' from D+, with a pass in English and Mathematics a must. Again through research, there is now a raised awareness among stakeholders on the issues of literacy, water and sanitation, and the consequences of not providing these.

As a means of achieving the stated objectives, as well as coping with the influx of new students into the primary sector in response to EFA, an Education Sector Strategic Plan (ESSP) has been developed. The aim is to further articulate the government's vision for development of Kenya's education sector and to identify strategic imperatives to achieve a high quality and efficient system. The ESSP envisions an education system that spells out the country's requirements for the economy. It also identifies the country's policy priorities and the overall framework embedded in quality, inclusion and enhanced participation. It is within this plan that resources for education are required. The ESSP has been agreed on and a sessional paper that sets strategic objectives for the sector has been drafted ready to be discussed by the cabinet. It will be the onus of the government to take upon itself to mobilize key stakeholders to institutionalize the ESSP objectives.

The process of developing the ESSP has involved extensive internal consultations within the Ministry of Education Science and Technology and its specialized agencies. The main targets as captured in the ESSP as far as primary education is concerned are: increased enrolment of pupils in classes 1-8, significant improvement in the 
quality of performance and standards of education, increased re-entry for teenage mothers and improved completion rates across all primary classes.

While these are laudable goals, and while the government is sincerely committed to achieving them, it will not be an easy task. The introduction of FPE has resulted in an additional 1.3 million children enrolling in primary schools. Currently about 7 million children attend Kenya's 17,500 primary schools. The rapid increase in numbers has triggered widespread concern about the quality of education in the primary sector, which is the foundation of the education sector as a whole, particularly in the absence of additional targeted resources to the sector. A chain reaction touching on teacher and facility adequacy, teaching methods, seating arrangements, working space, examination and assessment, water and sanitation has already set in. All of these are found to impact negatively on the quality of education offered to primary school children and if specific interventions are not undertaken in the immediate future, the situation will worsen.

\section{CONCLUSION}

The advantages of education cannot be denied. The prosperity of a country has been found to be linked closely with its educated populace and the standards of education. Education gives individuals the opportunity to get as good a job as they are capable of, and a chance to earn a better living than they otherwise would. It also develops one as an individual, enabling him to get more out of life. No obstacle, therefore, should prevent a child from receiving an education, and to delay giving this right would be wrong. However, the question is, What type of education?

There are a number of difficulties that stand in the way of providing every child with free education. For example, for those countries that are offering free primary education, it has not been possible to provide enough educational resources and facilities to accommodate the large numbers. Again, it has not been possible to give all children a secondary school education, as there are not enough secondary classrooms and teachers. So children are leaving school half educated, but expecting to make a living in a town as many who have had formal education shun farming. But there are not enough jobs available to provide employment to such a large number of job seekers. The towns are already full of discontented, unemployed school leavers. The government is under pressure to build more secondary schools and industries to accommodate school leavers.

As has been pointed out, it is not possible to have QE if there are not enough teachers and funds. The training colleges are not able to produce enough teachers for the increased enrolments, and it is not possible to obtain them from other places. Even if teachers were found, there would be the problem of getting funds to pay them. From the foregoing, it is clear that in order to provide $\mathrm{QE}$, the provision of primary education should not advance faster than: the increase in teachers to staff the schools, funds to pay for it, secondary school places and the increase in jobs creation.

The above challenges seem to affect the teacher more than anybody else as s/he is in a dilemma. Firstly, s/he is placed in a situation where s/he has to teach large classes without being prepared for it and without the appropriate resources. Secondly, the classrooms have pupils of all ages, a situation she was not prepared to handle. Despite teachers' worsening working conditions, their pay still remains low resulting to their low morale. There is, therefore, a need to embark on identifying solutions to the above challenges.

Teacher education would be the entry point for intervening. The key challenges are how to increase the number of teachers and improve their capacity to teach large classes consisting of varied age groups. They also need help on how to help rural and urban slum children master literacy. This would be done within a context in which many factors such as language policy, teacher education policy, assessment policy, classroom methods, provision of reading resources and student retention influence provision of QE.

The next strategy would be to start working on curriculum specifics, in particular examining the primary school curriculum to assess the challenges it presents to a teacher, particularly in rural areas. It is necessary to create an awareness of the need to emphasize acquisition and mastery of literacy in the first 3 grades of schooling since it is 
here, where the basic foundation for learning all other subjects is formed. It is hypothesized that if teachers have a clearly outlined description and direction on education policies, teaching methods, resources and assessment procedures, they should be able to teach more effectively and learners will be able to grasp better the concepts taught. This implies there should be a shift in training for the pre-service teacher and in-service training for the practicing teacher. Unless this is done, a substantial number of pupils may drop out and for those who remain, performance in all subjects in the curricula may continue to be poor as is the current pattern depicted by the results of summative national public examinations. Failure to pass in the examinations means such learners' chance to pursue further education is curtailed.

There is also a need for continuous monitoring and evaluation of learning by administering proficiency and diagnostic tests from time to time, to find out the attainment levels of learners, instead of waiting until they complete school to condemn the majority of them as failures. Ability to read was also found to be lacking in many learners. Development of the reading skills is vital as it is the backbone of information gathering. It is between grades 6 and 12 that learners greatly develop the power to comprehend (Robb, 2003). All learners have visual intelligence: the mental skill to organise and process information by seeing and creating images (Gardner, 1999). Exposing them to various materials would enable them to visualize many concrete and abstract ideas while reading, thereby sharpening their wit and gaining knowledge. There is a need, therefore, to produce affordable none-textbook materials, as they are lacking in the majority of schools.

\section{REFERENCES:}

1. Ayot, H. and Patel, M. (1992). Instructional Methods. Nairobi: Educational Research and Publications Ltd.

2. Brumfit, C. (1984). Communicative Methodology in Language Teaching. Camb.

3. Carson, D. (1990). Language Policy Across the Curriculum, Multilingual Matters.

4. Cook, V. J. (1981). "Using Authentic Materials in the Classroom”, Modern Teacher Vol. 9.

5. Cummins, J. (1980). “The Construct of Language Proficiency in Bilingual Education”, in Alatis 1980: 81-103.

6. Dugger, C. (2004). In Africa, Free Schools Feed a Different Hunger. New York Times, October 24.

7. Dutcher, N. (1985). "The use of First and Second Language in Education: A Review of International Experience". Washington D.C.: The World Bank.

8. Gardner, H. (1999). Frames of Mind: The Theory of Multiple Intelligence, New York: Basic Books.

9. Gathumbi, A. (1985). "Effects of Language Policy on the Mastery of English at Standard Four - A comparative study". A PGDE Dissertation, Kenyatta University. Hall (1987).

10. Kishore Singh, (2002). Legal Framework and the rights to Education-UNESCO's experience. UNESCO, Paris.

11. Lewin, J. (1985). "The Quality of the Teacher”, Journal of education, 50: 75-84.

12. Lopez, L. (2000). "Conditions for Success in Designing and Monitoring Programme Delivery in MultiLingual Settings". Washington D.C.: the World Bank Institute.

13. Omaggion, A. (1986). Teaching Language in Context. Profitably Oriented Instruction. Boston: Chapaign Heinle and Heinle Publishers Inc.

14. Muthwii, M. (2001). Language Policy and Practices in Education in Kenya and Uganda. Nairobi: Phoenix Publishers.

15. Robb, L. (2003). Teaching Reading in Social Studies, Science, and Math. New York: Scholastic.

16. Rockefeller Foundation (2004). "Development of English Literacy Norms for Primary Schools in Kenya". (Unpublished research report).

17. Rubagumya C. (2000). Choosing the language of Instruction in Post-colonial Africa: lessons from Tanzania. Washington D.C., the World Bank Institute.

18. Ryanga, C. (1994). "Construction and standardization of an English Language Literacy test for upper primary School Grade in Kenya”. Ph D Thesis, Kenyatta University.

19. Stern, H. (1983). Fundamental Concepts of Language Teaching. Oxford: Oxford University Press.

20. UNESCO, (2002). United Nations Literacy Decade: 2003-2012. UNESCO, Paris.

21. Weir C. (1990). Communicative Language Testing. London: Prentice Hall International. 
22. Wells, G. (1986). The Meaning maker: Children Learning Language and Using Language to Learn. London: Hodder and stroughton, London.

\section{NOTES}

